УДК 94 (517)

НОЛЕВ Евгений Владимирович - кандидат исторических наук; научный сотрудник отдела истории и культуры Центральной Азии Института монголоведения, буддологии и тибетологии СО РАН (670047, Россия, Республика Бурятия, г. Улан-Удэ, ул. Сахьяновой, 6; nolev@inbox.ru)

\title{
ИМПЕРСКИЕ ПРИНЦИПЫ В МОНГОЛЬСКОМ ЗАКОНОДАТЕЛЬСТВЕ ПЕРИОДА ПРАВЛЕНИЯ ЧИНГИС-ХАНА
}

Аннотация. Статья посвящена изучению правовых норм средневековой Монголии с целью определения принципов и положений, отражающих преобразование кочевой политии в Евразийскую империю. Автор приходит к выводу, что отдельные нормы права Чингис-хана раскрывают специфику политогенеза, при котором формирование империи, образуемой в результате интенсивной завоевательной политики, опережает развитие государственности и государственных институтов кочевого общества.

Ключевые слова: монголоведение, Чингис-хан, Великая монгольская империя, «Великая Яса»

$\mathrm{C}$

оздание Чингис-ханом Монгольской империи потребовало не только унификации права монгольских народов, составивших ядро формирующейся Евразийской сверхдержавы, но и разработки универсальных правовых норм, способных установить идею верховенства власти империи, не отменяя правовых традиций покоренных народов. Реализация данного глобального замысла обрела воплощение в монгольском средневековом праве в форме следования торе (порядок, закон, обычай), уникальному памятнику средневекового монгольского права «Их Засаг» («Великая Яса») и «биликам» (изречения Чингисхана).

Сегодня наряду с обобщением достижений отечественных и зарубежных историко-правовых монголоведных исследований обозначены направления научного поиска, связанные прежде всего с новыми концептуальными подходами, необходимостью совершенствования понятийно-категориального аппарата права монгольских народов, рассмотрения законов с позиций кочевой ментальности и влияния религиозного фактора. Так, Б.В. Базаров и Ц.П. Ванчикова, характеризуя опыт изучения «Великой Ясы», отмечают: «Жестко социологический, политический, правовой односторонний подход, оставляющий в стороне изучение ментальности различных этнических групп Центральной Азии, невольно влечет за собой модернизацию понятий и оценок средневекового правосудия монгольской государственности, интерполяцию на Ясу современных представлений о праве и, в конечном счете, определенное несоответствие в понимании ситуации в целом» [Монгольские народы... 2016: 75-76].

Традиционной нормой кочевого права, воплощенной в монгольской правовой системе, было торе (закон, обычай, правило). В.В. Трепавлов приводит следующие определения значения данного термина: 1) нормы обычного права, совокупность неписанных регламентаций в различных областях социальной и бытовой жизни кочевников; 2) обозначение ханской власти, управление государством; 3) «объединенная законом народная масса» [Трепавлов 2015: 62]. Применительно к политическим реалиям Монгольской империи ученый определяет торе как свод правил межулусных и внутриулусных отношений, регулировавших взаимоотношения глав улусов, ханов и подданных, иерархические степени старшинства и ритуал введения в почетные должности, допуская обозначение данным термином государственную власть и систему связанных с ней учреждений. К сфере руководства торе, в отличие от «Ясы», относились 
традиционные для кочевников аспекты административного законодательства: система крыльев; порядок выдвижения и провозглашения кандидатов на высшие управленческие и командные должности (включая хана); соправительство; завоевание и покорение окрестных народов; распределение доходов и трофеев [Трепавлов 2015: 65, 66]. Н.Н. Крадин и Т.Д. Скрынникова предполагают, что торе - это Высший закон, установленный Небом, существующий вне воли человека, которым человек руководствуется в своей деятельности [Крадин, Скрынникова 2006: 405, 406]. Хан в этом случае выступал не создателем, а проводником торе - исполнителем воли Неба.

Фрагменты и отдельные положения «Великой Ясы» Чингис-хана, зафиксированные и описанные в арабских, персидских, армянских и китайских источниках, давно стали предметом пристального изучения в отечественном и зарубежном востоковедении. В современной историографии сложились различные аргументированные позиции относительно содержания «Их Засаг», согласно которым памятник мог представлять, во-первых, свод законов, содержащий предписания права; во-вторых, совокупность норм, обычаев и традиций средневековых монголов; в-третьих, сборник изречений и поучений Чингисхана [Дугарова 2016: 102]. Н. Ням-Осор называет три источника «Их засаг»: основной внутренний, заключенный в обычном праве монгольских племен; дополнительный, представленный указными нормами Чингис-хана; внешний - влияние китайского права [Ням-Осор 2003: 94]. Основное противоречие в определении правовой сущности «Ясы» заключается в возможности ее признания либо отрицания в качестве кодифицированного законодательства. Оригинальная идея была высказана Р.Ю. Почекаевым, предполагающим, что термин «Великая Яса» означает «правопорядок», т.е. состояние законности, достигаемое соблюдением соответствующих норм [Почекаев 2016: 733].

Согласно устоявшейся точке зрения, законы «Великой Ясы» впервые были обнародованы в 1206 г. на Великом курултае при провозглашении Чингис-хана великим монгольским ханом [Lamb 1936: 73]. Исходя из предположения, что «Их засаг» не был единожды зафиксированным законом, ученые склонны предполагать, что текст свода законов подлежал совершенствованию и дополнениям как при жизни Чингис-хана после утверждения «Ясы» на Великом курултае 1206 г. в 1211, 1219 и 1225 гг., так и при его преемниках [Ням-Осор 2003: 94]. Остается открытым вопрос о способе фиксации положений «Великой Ясы»: письменной или устной традиции трансляции правовых норм. В подтверждение наличия в Монгольской империи письменного права историк из Внутренней Монголии Сайшиял ссылается на исследование китайского монголиста Вен Ду Жиена, доказавшего, что в 1206 г. появился Закон Чингис-хана, записанный на бумаге [Сайшиял 2006: 177]. Вопрос о наличии письменных законов имеет принципиальное значение для оценки зрелости государственности, однако для исследования конструирования имперской идентичности более важное значение должно уделяться анализу отдельных положений «Их засаг».

Также правовыми нормами являлись билики (билиги) - изречения Чингисхана, дополнявшие «Великую Ясу». В.А. Рязановский отождествлял одни билики с отрывками из самой «Ясы», в то время как другие - с пояснением общего духа законодательства Чингис-хана [Рязановский 1931: 12]. С.Г. Кляшторный и Т.И. Султанов определяют билики как процессуальный кодекс, согласно которому осуществлялся суд над нарушителями «Великой Ясы» [Кляшторный, Султанов 2004: 191]. Принимая во внимание содержание дошедших до нас биликов Чингис-хана и гипотезу о китайском происхождении обычая записывать изречения хана и издавать их после его смерти [Кляшторный, Султанов 2004: 190], мы можем предположить, что назначение биликов также заключалось в 
сохранении и аккумуляции политической мудрости правителя, необходимой для управления огромной империей. Данное предположение подтверждается фактом необходимости изучения биликов Чингис-хана Чингизидами и военной аристократией, а также той решающей ролью, которую порой играло знание биликов при выборе наследников престола в истории Монгольской империи.

Различия между правовыми нормами торе, «Великой Ясы» и биликов, как нам представляется, обусловлены, с одной стороны, степенью традиционности, с другой - авторством Чингис-хана. Если в случае с торе хан являлся лишь исполнителем воли Неба, следуя традициям кочевников, то в случае с «Великой Ясой» и биликами - составителем (с учетом различных мнений по этому поводу) и в различной степени - автором. При этом все указанные правовые нормы были использованы при конструировании имперского политикоправового поля.

Несмотря на то что правовая система Монгольской империи была основана на нормах правового регулирования в кочевом социуме, отчетливо прослеживается не только ее надплеменной, но и имперский характер, способствовавшей объединению завоеванных территорий. Утверждалась абсолютная власть хана над покоренными странами и поданными, обусловленная сакральностью монгольского правителя. Противоречащие хану и государству приговаривались к смертной казни [Сайшиял 2006: 181]. Предписания «Великой Ясы», касающиеся употребления императорского титула, обнаруживали стремление к централизации власти на всей территории империи и сосредоточении ее полноты в титуле «хан»: «Монголы владыку своего государства и знатных людей зовут с прибавлением должности после имени. Другие почетные титулы и звания не называются» [Сайшиял 2006: 178]. В то же время присутствовали рекомендации родственникам об употреблении личной формы обращения по отношению к правителю [Вернадский 2014: 116]. Таким образом, персонификация абсолютной власти хана в империи граничила с сохранением его положения как близкого родственника и старейшины рода в семье, формируя тем самым основания для будущих династических противоречий.

Имперский характер нового законодательства диктовал необходимость снижения значения родоплеменных отношений в складывающейся административной системе и политической роли родовой знати. Наряду с организацией общественного устройства в рамках десятичной системы и формированием абсолютного единоначалия хана, обращает на себя внимание билик Чингисхана, говорящий о том, что беки (начальники) тьмы, тысячи и сотни, которые приходят и слушают мысли Чингисхана в начале и в конце года, а затем возвращаются назад, могут начальствовать войском, в то время как «состояние тех же, которые сидят в своем юрте и не слышат мыслей, походит на камень, попавший в большую воду, или на стрелу, пущенную в тростниковое место: он исчезает. Таким людям не подобает командовать» [Рязановский 1931: 15]. Данное изречение Чингис-хана свидетельствует о новых принципах назначения командного состава, основанных не на происхождении, а на преданности и исполнительности командующих. Стоит отметить, что свидетельство об указанном изречении в работе Сайшияла характеризует и его антисепаратистскую направленность: «Ноены должны собираться два раза в год и выслушивать указания-наставления. Возвратившись обратно, должно лично устанавливать правила исполнения. Если они хорошо все учтут, дела пойдут успешно. Кто на словах следует моим указам, а вдали от глаз, тайком будут перечить, чинить препятствия, уподобятся камню, упавшему в воду, наконечнику, потерянному в траве, не смогут повелевать массами» [Сайшиял 2006: 178]. Однако слом родоплеменных устоев не был радикальным: так, члены Золотого рода сохраняли особые права 
и привилегии, заключающиеся, в частности, в более мягком наказании за нарушения предписаний «Великой Ясы», за которые полагалась смертная казнь. При этом при наличии корпоративной собственности на власть, связанной с привилегированным положением представителей рода Чингизидов [Крадин, Скрынникова 2006: 252], во фрагментах «Законов Чингис-хана», цитируемых Г. Лэмом, предусмотрена норма закрепления власти за единственным избранным императором: «запрещается под страхом смерти провозглашать кого-либо императором, если он не был избран ханами, князьями, военачальниками и другими представителями знати на общем собрании» [Lamb 1936: 214].

Провиденциализм толкования источника ханской власти трансформировался в принцип имперской политики, отраженный в положении «Великой Ясы», регламентирующий обращение с противником перед боем: «Если без сопротивления последуете за нами, то ваш покой не будет нарушен, и мирная жизнь укрепится. Если будете сопротивляться, какие страдание испытаете вы, об этом, кроме вечного синего неба, никто не знает» [Цэрэнбалтав, Минжин 2006: 27]. При этом Монгольская империя в правовом отношении позиционировалась выше других государств: «Ханское монгольское государство не есть одно среди других государств мира, а есть созданное соединение народов, государство всего мира» [Сайшиял 2006: 180]. Г.В. Вернадский определил указанный правовой статус как «мировую империю в процессе становления» [Вернадский 2014: 115]. Вместе с тем положения «Их засаг» предписывают формирование благоприятных условий для торговли и неприкосновенность посланников и вестовых. «Яса» утверждала принцип религиозной терпимости [Вернадский 2014: 116], значительно облегчавший интеграцию государств с различной конфессиональной идентичностью в состав империи. Наряду с сохранением местных правовых систем покоренных стран, нормы «Их засаг» были главенствующими при контактах правителей покоренных земель и представителей династии Чингис-хана.

Следует отметить, что укрепление и персонификация власти Чингис-хана, ставшего повелителем огромной империи, в условиях синонимичности понятий «закон» и «власть» в средневековой монгольской политико-правовой культуре [Дугарова 2016: 71] привели к формированию особой политико-правовой идеологии тюрко-монгольского мира, именуемой исследователями «Чингизово право». Суть концепции «чингизизма», согласно Р.Ю. Почекаеву, сводится к следующим основаниям: сохранение верховной власти за потомками Чингисхана; действие «Великой Ясы» как правопорядка, установленного Чингисханом для всей империи; религиозная толерантность [Почекаев 2018: 54].

Правовая система Монгольской империи периода правления Чингис-хана отражает специфику политогенеза, при котором формирование империи, образуемой в результате интенсивной завоевательной политики, опережает развитие государственности и государственных институтов кочевого общества, охарактеризованного Н.Н. Крадиным как суперсложное вождество [Крадин 2007: 285]. Следовательно, развитие политико-правовой системы, базирующейся на кочевых традициях, определялось реакцией на быстро меняющуюся политическую ситуацию в форме создания правовых принципов имперского характера, призванных унифицировать представления о власти и обеспечить условия для интеграции покоренных народов в состав державы Чингис-хана.

Статья подготовлена в рамках государственного задания ФАНО России (проект ХІІ.191.1.2. «Межкультурное взаимодействие, этнические и социально-политические процессы в Центральной Азии», номер госрегистрации № $A$ AAA-A17-117021310264-4). 


\title{
Список литературы
}

Вернадский Г.В. 2014. Монголы и Русь. М.: Ломоносовъ. 512 с.

Дугарова С.Ж. 2016. Историография монгольского государства и права (XIII - начало XIX в.). Улан-Удэ: Изд-во Бурятского госуниверситета. 332 с.

Кляшторный С.Г., Султанов Т.И. 2004. Государства и народы Евразийских степей. Древность и средневековье. СПб: Петербургское востоковедение. 368 с.

Крадин Н.Н., Скрынникова Т.Д. 2006. Империя Чингис-хана. М.: Восточная литература. 557 с.

Крадин Н.Н. 2007. Кочевники Евразии. Алматы: Дайк-Пресс. 416 с.

Монгольские народы: исторический опыт трансформации кочевых сообществ Азии (отв. ред. Б.В. Базаров). 2016. Иркутск: Оттиск. 624 с.

Ням-Осор Н. 2003. Монгольское государство и государственность в ХIII$X I V$ вв. Улан-Удэ: Изд-во БНЦ СО РАН. 288 с.

Почекаев Р.Ю. 2016. Chinggis Khan's Great Yasa in the Mongol Empire and Chinggisid States of the $13^{\text {th }}-14^{\text {th }}$ Centuries: Legal Code or Ideal "Law and Order"? - Золотоордынское обозрение. № 4. С. 724-733.

Почекаев Р.Ю. 2018. Степные империи Евразии: власть - народ - право (очерки по политической и правовой антропологии). Алматы: «АБДИ Компани». 218 с.

Рязановский В.А. 1931. Монгольское право (преимущественно обычное). Харбин: Типография Н.Е. Чикарева. 350 с.

Сайшиал. 2006. Сказание о Чингисхане. Улан-Удэ: Республиканская типография. 576 с.

Трепавлов В.В. 2015. Степные империи Евразии: монголы и татары. М.: Квадрига. 386 с.

Lamb H. 1936. Genghis Khan. The Emperor of All Men. London: Thornton Butterworth Ltd. 303 p.

Цэрэнбалтав С., Минжин Ц. 2006. Тэмужсин-Чингис хааны «Их Засаг» Хууль. Уланбаатар: АРТСОФТ. 140 с.

NOLEV Evgeniy Vladimirovich, Cand.Sci. (Hist.), Researcher at the Institute for Mongolian, Buddhist and Tibetan Studies, Siberian Branch of Russian Academy of Sciences (6 Sah'janovoj St, Ulan-Ude, Republic of Buryatia, Russia, 670047; nolev@inbox.ru)

\section{IMPERIAL PRINCIPLES IN THE MONGOLIAN LEGISLATION IN THE REIGN OF GENGHIS KHAN}

\begin{abstract}
The article is devoted to the Mongolian legislation in the reign of Genghis Khan. Based on the analysis of the reconstructed positions of the Tore, Great Yasa and the biligs (sayings of Genghis Khan), the imperial principles of the law of medieval Mongolia are revealed. These principles include the legitimacy of the absolute power of a khan, universal supremacy of the Mongolian empire over other states, religious tolerance. These rules of the law reveal the specifics of the political genesis of the Genghis Khan's state. The author concludes that the development of the empire, formed as a result of intensive conquests, was ahead of the establishment of statehood and state institutions of the nomadic society.

Keywords: Mongolian studies, Genghis Khan, Great Mongol Empire, Great Yasa
\end{abstract}

